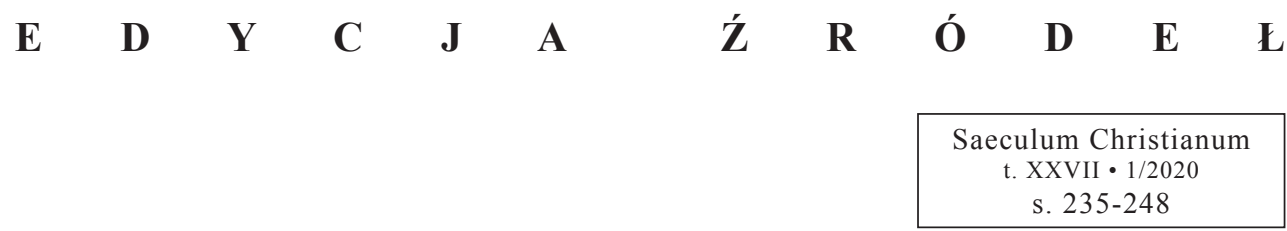

\author{
KS. TOMASZ MOSKAL ${ }^{1}$ \\ Lublin \\ ORCID: 0000-0002-0174-893X
}

\title{
INWENTARZE PARAFII RACŁAWICE Z 1940 I 1954 ROKU
}

$\mathrm{P}$ arafia p.w. św. Stanisława biskupa i męczennika w Racławicach, która obecnie znajduje się $w$ granicach diecezji sandomierskiej, została erygowana na przełomie XIII i XIV w. ${ }^{2} \mathrm{~W}$ okresie staropolskim przynależała do diecezji krakowskiej, archidiakonatu sandomierskiego (erygowanego pod koniec XII w.) i dekanatu rudnickiego (utworzonego na przełomie XVI i XVII w.). W 1772 r., na skutek rozbiorów Polski, odłączono ją od stolicy w Krakowie i w 1776 r. stała się na kilka miesięcy częścią diecezji tarnowskiej. Po regulacji granic z diecezją przemyską, która miała miejsce w tym samym roku, weszła w jej skład na ponad 200 lat $^{3}$. Dopiero papież Jan Paweł II bullą Totus Tuus Poloniae Populus włączył ją do diecezji sandomierskiej. Terytorium parafii obejmowało wsie szlacheckie: Racławice, Przędzel, Wolina, Nowa Wieś, Stróża, Huta Deręgowska i królewskie: Nisko, Zarzecze oraz Zaosicze, jak również pomniejsze osady, zanikłe na skutek wojen czy wylewów Sanu. W XIX w. dołączono Nowosielec, Podwolinę i część Kończyc, dzięki czemu stała się wówczas bardzo rozległą parafią ${ }^{4}$.

Nie wiadomo, ile kościołów w niej postawiono. Informacje źródłowe z początku XVIII w. ukazują świątynię dość mocno zniszczoną. W Aktach Kapituły Kolegiackiej w Sandomierzu, w których znajduje się informacja, że Racławice były uposażeniem kanonika kaznodziei, zapisano w 1723 r.: „Podłoga z tarcic, okna grad wybił i dach podziurawił”. Kolejny właściciel części Racławic i Przędzela, podczaszy wieluński Józef Grabiński, który zakupił te dobra po 1730 r., ufundował nowy kościół. Został on uroczyście konsekrowany 26 października 1742 r. przez sufragana krakowskiego Michała Kunickiego (1698-1751) ${ }^{6}$. Służył parafianom do 1914 r. W czasie działań wojennych na linii Sanu „spłonął doszczętnie

\footnotetext{
1 Ks. Tomasz Moskal - dr hab. historii Kościoła, prof. KUL; pracownik naukowo-dydaktyczny w Instytucie historii Kościoła i Patrologii KUL; e-mail: tomos@kul.pl.

2 J. Rawski, Wybrane zagadnienia dotyczace administracji kościelnej w widłach Wisty i Sanu, Tarnobrzeg 1997, s. 31; W. Kowalski, Uposażenie parafii archidiakonatu sandomierskiego w XV-XVIII wieku, Kielce 1998, s. 353-354; B. Kumor, Dzieje diecezji krakowskiej do roku 1795, t. 4, Kraków 2002, s. 212.

3 B. Kumor, Ustrój i organizacja Kościoła polskiego w okresie niewoli narodowej 1772-1918, Kraków 1980, s. 161.

4 Rocznik Diecezji Sandomierskiej 1994, red. Z. Kończak, Sandomierz 1994, s. 226-227.

5 J. Wiśniewski, Katalog prałatów i kanoników sandomierskich od 1186 do 1926 r. tudzież sesje kapituły sandomierskiej od 1581 do 1866 r., Radom 1928, s. 139.

6 J. Kracik, Konsekracje kościolów i oltarzy w diecezji krakowskiej w XVII-XVIII w., „Nasza Przeszłość”, 61 (1984), s. 140.
} 
z całym wyposażeniem i przyborami liturgicznymi. Nabożeństwo wśród murów plebanii częściowo tylko ocalałych"?.

Duchowni z parafianami podjęli się trudnego dzieła budowy nowej świątyni. Mimo zniszczenia kraju i ubóstwa ludności oraz starań o odłączenie ekspozytury w Nisku i utworzenia w nim oddzielnej parafii (co nastąpiło w 1928 r.), już 8 maja 1922 r. poświęcono nowy kościół. Nadal jednak kontynuowano wyposażanie świątyni w potrzebne paramenty liturgiczne. Trwało cały okres międzywojenny. Ilustracją tych działań są cztery protokoły zdawczo-odbiorcze i inwentarze parafialne. Sporządzono je, po dwa w danym roku kalendarzowym, w 1923 i 1930 r. Natomiast stan kościoła u progu II wojny światowej i w pierwszych latach po jej zakończeniu ilustrują publikowane niżej inwentarze z 1940 i 1954 r. Wszystkie te źródła są przechowywane w archiwum parafialnym w Racławicach.

\section{Podstawa wydania}

Pierwszym dokumentem edytowanym jest „Inwentarz parafii rz. kat. w dekanacie Rudnickim diecezji Przemyskiej ob. łac. 1940”. Rękopis, spisany na ośmiu kartach papieru kancelaryjnego, został sporządzony przez ówczesnego proboszcza ks. Franciszka Zmarzłego (1889$1956)^{8}$. Opisywany jest w nim kościół i kaplice z wyposażeniem, pozostałe budynki, księgi i dokumenty kościelne oraz inwentarz. Natomiast dokument z 1954 r. nosi tytuł „Protokół z przejęcia kościoła i probostwa w Racławicach przez Ks. Mieczysława Porawskiego, wikariusza, substytuta, z rąk Ks. Franciszka Zmarzłego, proboszcza w Racławicach, udającego się na roczny urlop, spisany w obecności ks. Wincentego Boczara, dziekana dekanatu rudnickiego, w Racławicach, dnia 10 października 1954 r.”. Jest to maszynopis spisany dwustronnie na jednej karcie. Obejmuje dwie części: inwentarz kościoła i inwentarz probostwa. Wyraźnie w nim zaznaczono, co ubyło od czasu sporządzenia ostatniego inwentarza, a co przybyło.

\footnotetext{
Wykaz kościołów diecezji przemyskiej ob. łać. wskutek wojny całkowicie zniszczonych lub częściowo uszkodzonych, „Kronika Diecezji Przemyskiej”, 17 (1917), s. 49.

8 Ks. Franciszek Zmarzły (1889-1956). Po przyjęciu święceń kapłańskich pracował jako wikariusz w parafiach: Sieniawa oraz Grodzisko. 1 lipca 1918 r. został wikariuszem w Racławicach. Pracował do 30 czerwca 1922 r. Przez 8 lat duszpasterzował jako wikariusz w pobliskich Kopkach. Od 21 lipca do 7 października 1930 r. był administratorem, zaś od 8 października proboszczem w Racławicach. Po 24 latach pracy, 10 października 1954 r., udał się na urlop zdrowotny. Zmarł 11 kwietnia 1956 r. Archiwum Archidiecezji Przemyskiej (dalej: AAP), Akta personalne księży (dalej: Apk), Tabela służbowa (dalej: Ts.), lit. „Z”, Tabela służbowa ks. Franciszka Zmarzłego; T. Moskal, Duszpasterze parafii Racławice w latach 1918-1939, „Archiwa Biblioteki i Muzea Kościelne”, 92 (2009), s. 170-171 .
} 
I.

\section{Inwentarz parafii rz[ymsko] kat[olickiej] w dekanacie Rudnickim diecezji Przemy- skiej ob[rządku] lac[ińskiego] 1940.}

A.

Inwentarz kościoła

I.

1. Kościół - pod wezwaniem św. Stanisława, zbudowany w r. 1921 z krzyżaków, obity zewnątrz i wewnątrz deskami, o 16 oknach z zakrystią z jednej strony i skarbcem z drugiej strony. Otynkowany wewnątrz w r. $1937^{9}$.

Opis zewnętrzny - 4 drzwi z cementowymi stopniami, cokół murowany, dach z blachy ogniotrwałej w dobrym stanie, 2 krzyże.

Opis wewnętrzny - prezbiterium, nawa główna i 2 nawy boczne oraz przedsionek, rozmiary 29×13, os[ie]m filarów, balaski z drzewa, chór z desek $13 \times 3$ ze schodami na strych. Ogrodzenie drewniane, dość dobre.

2. Wieżyczka - drewniana, zbudowana wraz z kościołem, szer. 1 m, wys. 5 m, zakończona krzyżem, mieści sygnaturkę.

II.

Kościoły i kaplice

3. Kapliczka na Podwolinie ${ }^{10}$, na parceli gminy Nisko sprzed wojny pod wezwaniem M[atki] B[ożej] Niep[okalanie] Poczętej, murowana o 4 oknach, rozmiar 8×4,5. Ołtarz prowizoryczny z obrazem M[atki] B[ożej] Różańcowej, okolony wieńcem sztucznych kwiatów. Do kapliczki należą:

- 4 lichtarze drewniane, malowane

- 4 obrazy ścienne w ramach

- 2 lawki drewniane, proste

- 1 krzyżyk metalowy

- 1 dzwonek do mszy

- 1 mała sygnaturka na wieżyczce.

Kapliczka zewnątrz i wewnątrz bielona, parkan malowany w dobrym stanie.

4. Kapliczka w Przędzelu ${ }^{11}$ na parceli dawnego dworu, odrestaurowana w r. 1914, pod wezwaniem M[atki] B[ożej] Leżajskiej, murowana o 2 oknach, rozmiar 7×3, kryta blachą. Ołtarz składa się z płyty oraz obrazu M[atki] B[ożej] Leżajskiej wys. 1,5 m. Inwentarz tworzą:

- 4 lichtarze mosiężne

- 2 obrazy ścienne

- 2 półki drewniane, przymocowane

\footnotetext{
9 Koszt tynkowania kościoła wyniósł 4876 zł 46 gr. Archiwum Parafii Racławice (dalej: APR), Księga dochodów i rozchodów, Rachunki tynkowania kościoła, 1938 r.

10 Kaplica mszalna w Podwolinie została wybudowana w latach 1905-1907 staraniem członków Związku katolicko-społecznego (Sprawozdanie z pracy katolicko-społecznej w diecezji przemyskiej za czas od sierpnia 1911 roku, tj. od Kongresu Mariańskiego, do czerwca 1914 r., „Kronika Diecezji Przemyskiej”, 14 (1914), z. 6, s. 370.

11 Tamże. O eremie z tercjarzem franciszkańskim w Przędzelu są poświadczone źródłowo informacje z $1740 \mathrm{r}$. W 1764 było tam również prywatne oratorium Zamojskich. W. Kowalski, Uposażenie parafii, dz. cyt., s. 354.
} 
- 1 kropielnica metalowa

- 1 krzyżyk mosiężny

- 1 mała sygnaturka na wieżyczce.

Oparkanienie w dobrym stanie, natomiast położenie kapliczki b[ardzo] niedogodne, gdyż znajduje się ona bezpośrednio przy drodze bitej.

[s. 2]

III.

5. Cmentarz - ogrodzony od strony frontowej siatką drucianą, zaś z 3 pozostałych parkanem na słupach cementowych, brama żelazna z zamkiem, trupiarnia murowana z r. 1908 kryta dachówką, wewnątrz kuchenka z cegieł, drewniany stół specjalny oraz miednica ${ }^{12}$.

IV.

6. Ołtarze -2 boczne i 1 główny, prowizoryczne i zbudowane z desek.

V.

7. Chrzcielnicy nie ma.

VI.

8. Ambona prowizoryczna, z desek ze schodkami.

VII.

8. Harmonia nożna dwugłosowa $\mathrm{z}$ pedałem ${ }^{13}$.

VIII.

9. Dzwony - jeden w dzwonnicy, sygnaturka na wieżyczce, harmonijny dzwonek przy zakrystii, dwa harmonijne dzwonki ołtarzowe oraz 4 pojedyncze dzwonki ${ }^{14}$.

Dzwonnica - piętrowa z r. 1911 murowana, kryta blachą, odnowiona w r. $1937^{15}$.

12 Cmentarz parafialny założony w początkach XIX w. na planie kwadratu został usytuowany na południowo-wschodnim krańcu Racławic. Zabytkowe cmentarze i mogity w Polsce. Województwo tarnobrzeskie, opr. M. Florek, Warszawa 1995, s. 122-123.

13 Fisharmonię zakupiono w Krakowie za 170000 marek (dalej: mk). Na jej naprawę wydawano od 1930 r.: 5 zł w 1933 r., 13 zł 77 gr w 1934 r., 6 zł 50 gr w 1936 r., 30 zł w 1939 r. APR, Księga dochodów i rozchodów, passim.

14 Dzwon został odlany w $1663 \mathrm{r}$. Ważył $110 \mathrm{~kg}$ i miał średnicę $58 \mathrm{~cm}$ i wysokość $45 \mathrm{~cm}$. Został zarekwirowany przez Niemców 25 października 1941 r. W archiwum parafialnym w Racławicach jest dokument, opatrzony datą 27 lutego 1942 r., potwierdzający rekwizycję. Zabrano wówczas także drugi dzwon, który znajdował się na cmentarzu. Miał on wagę $23 \mathrm{~kg}$, średnicę $36 \mathrm{~cm}$ i wysokość $31 \mathrm{~cm}$. Został odlany w 1920 r. APR, Dokumenty luźne; AAP, Teczka z ankietami z 1945 r. o stanie parafii w czasie II wojny światowej, Teczka „K-Z”, Dekanat rudnicki, Ankieta parafii Racławice - błędnie podano rok - 1943.

15 Wydatkowano wówczas m.in. na 7 sztuk desek do dzwonnicy 17 zł 50 gr, deski 36 zł 50 gr, naprawę dachu 108 zł. APR, Księga dochodów i rozchodów, Rachunki tynkowania kościoła, 1938 r. 
IX.

Sprzęty ze złota i srebra

10. Monstrancja pozłacana $\mathrm{z}$ posrebrzanym wianuszkiem z liści, z futerałem ${ }^{16}$.

11. Kielichy 3 (miedziane, pozłacane zewnątrz i wewnątrz, jeden ze srebrnym kubkiem).

12. Puszki 2 (jedna miedziana cała pozłacana, druga srebrna, cała złocona).

13. Naczyńka 2 dla chorych, pozłacane.

14. Naczyńko 1 do chrztu, srebrne.

$\mathrm{X}$.

Sprzęty z metali nieszlachetnych

15. Tacki cynowe (1 do Komunii św., 2 od ampułek oraz 1 większa do zbierania składek).

16. Trybularz metalowy 1.

17. Łódka do kadzidła 1.

18. Kropielnica cynowa 1.

19. Kropidło metalowe 1.

20. Lawabo cynowe (złożone z zbiornika i podstawki).

21. Krzyż procesjonalny, mosiężny 1 .

22. Krzyże stojące na ołtarzu 3.

23. Krzyż ręczny 1.

24. Kociołek na wodę 1 (posrebrzany).

25. Zbiornik żelazny z przykryciem, na wodę chrzcielną.

26. Lawaterz szklany 1.

27. Lampa wieczna z brązu.

28. Lichtarze w liczbie 42 (w tym: 18 metalowych, 6 mosiężnych większych - sprawionych w r. 1938, 6 małych cynowych oraz 12 drewnianych czarnych - pogrzebowych).

[s. 3]

XI.

Sprzęty z drzewa

29. Komoda - sosnowa, malowana, składająca się z 3 części, liczących w sumie 18 szuflad różnej wielkości ${ }^{17}$.

30. Szafki sosnowe 3 na komodzie, jako schowek na wino, kielichy itp.

31. Stolik sosnowy, malowany ad lawabo ${ }^{18}$.

32. Wieszadło ozdobne malowane ad lawabo.

33. Krzyże drewniane 3 (jeden w ołtarzu głównym, drugi używany w czasie wielkanocnym oraz pogrzebowy).

34. Ławki z oparciem malowane ciemno 11.

16 Monstrancja została zakupiona w firmie Mariana Męcińskiego w Przemyślu w 1940 r. za 2000 zł. Wśród fundatorów - złożył 100 zł - był pochodzący z Racławic ks. Józef Kopeć (1912-1944), który został wyświęcony na kapłana 25 czerwca 1939 r. Zamordowany przez bojówkę UPA 12 lipca 1944 r. APR, Księga dochodów i rozchodów, 1940 r.; H. Borcz, Kopeć Józef, w: Słownik biograficzny duchowieństwa metropolii lwowskiej obrządku łacińskiego ofiar II wojny światowej 1939- 1945, red. J. Krętosz, M. Pawłowiczowa, Opole 2007, s. 103-104.

17 Na komodę wydano w 1936 r. 45 zł. APR, Księga dochodów i rozchodów, 1936 r.

18 Stolik ten zakupiono w 1936 r. za 15 zł 50 gr. APR, Księga dochodów i rozchodów, 1938 r. 
35. Ławki zwykłe, heblowane, 7 różnej wielkości, ustawiane wzdłuż ścian.

36. Konfesjonały w liczbie 10 malowane, w tym 1 pleciony.

37. Krzesła zwykłe 4.

38. Klęczniki 2 (1 dębowy, 1 sosnowy).

39. Katafalk 1 odmalowany z 3 schodkami ${ }^{19}$.

40. Trumna 1 odmalowana.

41. Pulpity dębowe, politurowane 2 .

42. Stopnie ołtarzowe 3 i jeden w zakrystii.

43. Paschał ozdobny 1 wraz z nadstawką.

44. Trójząb drewniany 1.

45. Pudełko dębowe, politurowane na oleje.

46. Skrzynia na kwiaty, figurki itp.

47. Mary drewniane 2.

XII.

Inne sprzęty

48. Antepedium 1 malowane na płótnie.

49. Baldachim 1, stary.

50. Poduszki pod mszał 2, stare.

51. Ampułki 4 pary.

52. Lampy naftowe, zwykłe w liczbie 6.

53. Dywany 3 (wielki przed głównym ołtarzem, 2 boczne mniejsze, z tych 1 b[ardzo] wytarty.

\footnotetext{
[s. 4]

XIII.
}

Szaty liturgiczne

54. Kapy w liczbie 5 (w tym: 2 białe z których jedna b[ardzo] zużyta, 1 zielona, 1 fioletowa oraz 1 czarna, wszystkie w dobrym stanie).

55. Ornaty razem 19 (2 zielone, przy czym 1 zużyty, 2 fioletowe zwykłe bez ornamentyki z których 1 bardzo zniszczony, 4 czerwone, z których 2 gorsze, 2 natomiast nowe zakupione w r. 1937 i 8 z brokatu z ornamentyką, jeden z postacią św. Stanisława, haftowany złotem, używany od większych uroczystości, 8 białych ornatów, pośród których 5 prostych, bez specjalnych ozdób, jest mniej lub więcej zużytych, natomiast 3 są nowsze: mianowicie 1 ze św. Franciszkiem w kolumnie, starszy lecz w dobrym stanie oraz 2 nowe z r. 1937 i 9 z brokatu wzorzystego: jeden $z$ haftowanym złotym wizerunkiem M[atki] B[ożej] Niep[okalanej] używany tylko w czasie uroczystych świąt, 3 ornaty czarne, dwa częściowo zużyte, jeden nowy, zakupiony w r. 1937 prosty bez ozdób).

56. Sukienki 2 (jedna taftowa, malowana ręcznie, druga jedwabna).

57. Tuwalnie 2, z których 1 zniszczona, druga nowa, ręcznie haftowane - dar Koła Gospodyń Wiejskich z Racławic z r. 1938.

19 Katafalk kosztował w 1937 r. 25 zł. APR, Księga dochodów i rozchodów, 1938 r. 
58. Welon na monstrancję $1^{20}$.

59. Konopeum 3 (w kolorze białym starsze, zielonym - dar Kursu kroju i szycia z r. 1937 w Racławicach, oraz białe konopeum z wzorzystego brokatu z tronem, specjalnie do wystawień Najśw[iętszego] Sakramentu.

60. Umbracula 1 z kunsztownego brokatu, naszychowana złotem, na metalowej podstawce.

61. Nakrycia na ołtarze 5 (2 bardzo zużyte, 1 w dobrym stanie, 1 ofiarowane w r. 1938 przez X.).

62. Nakrycia na ambonę 2 .

63. Stuły w liczbie 15 (13 fioletowych do spowiedzi, mniej lub więcej zużytych, 1 zielona w dobrym stanie oraz takaż biała).

64. Bursy 2 (proste, jedna w gorszym stanie).

XIV.

Bielizna kościelna

65. Alby w liczbie 5, tylko 2 bardziej zużyte.

66. Humerały w liczbie 20 (stan jakościowy przeważnie dobry, 10 nowych).

[s. 5]

67. Komże w liczbie 7.

68. Komeszki [sic!] dla ministrantów 4, w dobrym stanie.

69. Kołnierzyki dla ministrantów po 1 parze w kolorze zielonym, czerwonym i fioletowym - nowo sprawione ${ }^{21}$.

70. Paski 3 w dobrym stanie, 4-ty nie do użycia.

71. Korporały 16, wszystkie dobre.

72. Palki 21, wszystkie dobre.

73. Ręczniczki 15, wszystkie dobre.

74. Puryfikaterze 25, jakkolwiek starsze w dobrym stanie.

75. Obrusy 16 (w tym 13 wierzchnich oraz 3 spodnie, lniane, podwójne).

76. Obrusiki do balasek - 2 zmiany, nowo wprowadzone.

77. Obrusiki na tabernakulum 6, koronki do obrusów 7 sztuk.

XV.

Obrazy, chorągwie, figury

79. Obrazy w sumie 19: 14 stacji drogi krzyżowej, olejno ręcznie malowanych w ramach sosnowych ${ }^{22}$, 1 olejny obraz o rozm[iarach] 3×2 w głównym ołtarzu wyobrażający P[ana]

\footnotetext{
20 Welon na monstrancję kupiono w 1921 r. za 310 mk. PR, Księga dochodów i rozchodów, 1921 r.

21 Kupione w 1935 r. za 11 zł. APR, Księga dochodów i rozchodów, 1935 r.

22 Obrazy ze stacjami drogi krzyżowej zakupiono w 1922 r. za 46000 mk. Ich autorem był malarz Jan Bukowczyk z Krakowa. Po przesłaniu do Racławic, zostały oprawione przez nieznanego z imienia stolarza o nazwisku Woźniak w ramy sosnowe. Za swoją usługę otrzymał wynagrodzenie w wysokości 80000 m. APR, Księga dochodów i rozchodów, $1921 \mathrm{r}$.
} 
Jezusa w Ogrójcu - dar p[ani] Waldekowej ${ }^{23}, 2$ obrazy (św. Teresy i św. Franciszka ${ }^{24}$ ) w ołtarzach bocznych za szkłem, 1 obraz M[atki] B[ożej] Ostrobramskiej w ramach dębowych oraz mały obraz św. Teresy od Dzieciątka Jezus.

80. Figury 4 (Serca J[ezusa] oraz M[atka] B[oża] Niep[okalanie] Poczęta wys. $1 \mathrm{~m}$ [etra] w ołtarzach bocznych, figura zmartwychwstałego J[ezusa] wys[okości] 0,5 m[etra], Chrystus $\mathrm{z}$ grobu $1 \mathrm{~m}[\mathrm{etr}]$, wszystkie $\mathrm{w}$ dobrym stanie $)^{25}$.

81. Chorągwie 8 (2 czerwone sukienne stare, 2 pary nowo sprawionych w r. 1937 i 8 z obrazami malowanymi na płótnie, z barwnego brokatu wraz z pokrowcami z szarego płótna i taftowymi szarfami) oraz 2 chorągwie czarne w dobrym stanie ${ }^{26}$.

82. Feretrony w liczbie 5 ( 2 drewniane i 1 metalowy starsze, natomiast 2 zakupione w r. 1936 i 7 i 8, figura św. Teresy z specjalnej masy, z funduszów i składek K[atolickiego] S[towarzyszenia] M[łodzieży] Żeńskiej w Racławicach, oraz statua św. Franciszka zakupiona ze składek Żeńskiego III-go zakonu św. Franciszka ${ }^{27}$.

83. Kanony w liczbie 9 (6 w oprawie metalowej, $3 \mathrm{w}$ drewnianej).

84. Praeparatio ad missam $1 \mathrm{w}$ ramach dębowych.

[s. 6]

XVI.

\section{Książki}

85. Mszały 4 (2 zwykłe duże oraz 2 żałobne).

86. Rytuały 2 (prócz tego 3 mniejsze książeczki).

87. Ewangelie na niedziele 2.

XVII.

Dyplomy w kościele i zakrystii

88.

a. Dokument ustanowienia Drogi Krzyżowej z r. 1922 w ramach dębowych.

b. Dokument erekcji III Zakonu św. Fr[anciszka].

c. Dokument erekcji Krucjaty Eucharyst[ycznej] wraz z nominacją Dyrektora ${ }^{28}$.

\footnotetext{
23 Zarówno darczyńcą jak i autorką obrazu była Maria Waldeck, żona Mieczysława Józefa Waldecka (1879-1945). Od 1917 r. był on właścicielem zespołu dworsko-pałacowego z folwarkiem w Racławicach. S. Gurba, Twórczość artystyczna Marii Waldeck - malarki z Królewskiej Wsi Pysznica, „Kronika Diecezji Sandomierskiej”, 107 (2014), nr 5-6, s. 391-396; B. Barć, Mieczysław Fusek, w: Przeszli przez tę ziemię czyniąc dobro. Cmentarz w Racławicach, red. B. Barć, Stalowa Wola 2012, s. 96.

24 Obraz przedstawiający św. Franciszka kosztował w 1937 r. 3 zł. APR, Księga dochodów i rozchodów, 1937 r.

25 Jednym z ofiarodawców figury Matki Bożej była Agnieszka Rękas, która złożyła na ten cel ofiarę 7500 mk. Natomiast na statuę Jezusa w grobie ówczesny proboszcz ks. Wojciech Sapecki (1844-1922) złożył dar w wysokości $4200 \mathrm{mk}$. APR, Księga dochodów i rozchodów, $1921 \mathrm{r}$.

${ }^{26}$ W archiwum parafialnym w Racławicach znajduje się luźna karta opatrzona datą 20 grudnia 1937 r. następującej treści: „Sztandar wielkości 90 x $125 \mathrm{~cm}$... artystycznie maszynowo haftowany, obszyty jedwabną frendzlą i galonem koloru złotego, z drzewcem i pełnym przepisowym okuciem kosztować będzie 180 zł”. Adresatem jest „Dom Bławatów i hurtownia liturgiczna" Antoniego Szancera z Poznania. APR, Dokumenty luźne.

27 Figura św. Franciszka kosztowała 162 zł, zaś św. Teresy 193 zł. APR, Księga dochodów i rozchodów, 1937 r.

28 Krucjatę Eucharystyczną erygował w Racławicach 15 listopada 1932 r. Wojciech Trubak SJ (1869-1949), rektor kolegium w Starej Wsi. ApR, Teczka z dyplomami; Encyklopedia wiedzy o jezuitach na ziemiach Polski $i$ Litwy 1564-1995, opr. Ludwik Grzebień, Kraków 1996, s. 701.
} 
d. Dokument erekcji Apostolstwa Modlitwy ${ }^{29}$.

89. Spis mszy fundacyjnych.

a. Za duszę śp. Józefa Reichla

b. Franciszki Warchoł ${ }^{30}$

c. Konstancji Kłódzickiej

d. Agnieszki Małek ${ }^{31}$

e. Andrzeja i Anny Byra

f. Marcina i Franciszki Dąbek ${ }^{32}$

g. Andrzeja Warchot ${ }^{33}$

h. Józefa i Zofii Warchoł ${ }^{34}$

i. Anieli Kostheim

j. Katarzyny Reichel (2 msze fundowane za jej duszę w r. 1935 w kwocie 300 zł. złożonych w K.K.O. w Przemyślu 96.064).

XIX.

Prawa rzeczowe - służebności

91. a. Żadnych praw rzeczowych nie ma.

b. Nie wydatkuje się.

c. Wydatki liturgiczne pokrywa się z dobrowolnych składek niedzielnych parafian.

XX.

Budynki kościelne

92. 1. Organistówka zniszczona w czasie wojny została rozebrana, a materiał zużyto na wybudowanie:

a. Stodoły drewnianej krytej dachówką.

b. Stajni drewnianej z przegrodą dla świń.

c. Szopy drewnianej

(wszystkie 3 pomieszczenia stanowią 1 budynek).

29 W archiwum parafialnym w Racławicach znajdują się dwa dyplomy Apostolstwa Modlitwy, których adresatem był ks. Franciszek Zmarzły. Pierwszy wystawiony w Starej Wsi 15 listopada 1932 r. przez wyżej wymienianego Wojciecha Trubaka SJ. Drugi został podpisany 18 czerwca 1933 r. przez krajowego dyrektora Apostolstwa Modlitwy Józefa Andrasza SJ (1891-1963). Na uwage zasługuje dopisana w nim informacja o renowacji dyplomu z 1881 r. ApR, Teczka z dyplomami; Encyklopedia wiedzy, s. 9.

30 Fundację mszalną za rodziców na sumę 200 koron złożył na ręce ks. Wojciecha Sapeckiego 12 marca 1908 r. Franciszek Dąbek z Warchołów. AAP, Teczki parafialne (dalej: Tp.), Teczka parafii Racławice (dalej: TpR) 2, Racławice 12 marca 1908 r., Akt fundacyjny, s. 3-4.

31 Agnieszka Małek z Przędzela zapisała w testamencie z 30 maja 1911 r. 200 koron na fundację mszalną za siebie. AAP, Tp., TpR 2, Racławice 17 kwietnia 1912 r., Akt fundacyjny, s. 7-8.

32 Fundację mszalną na sumę 200 koron złożył na ręce ks. Wojciecha Sapeckiego 10 kwietnia 1907 r. Jędrzej Warchoł z Kończyc. AAP, Tp., TpR 2, Racławice 10 kwietnia 1907 r., Akt fundacyjny, s. 1-2.

33 Fundację mszalną za ojca na sumę 200 koron złożyła na ręce ks. Wojciecha Sapeckiego 12 stycznia 1910 r. Agnieszka Kopeć z Kończyc. AAP, Tp., TpR 2, Racławice 12 stycznia 1910, Akt fundacyjny, s. 1-2.

34 Fundację mszalną na sumę 400 koron złożył na ręce ks. Wojciecha Sapeckiego 19 października 1913 r. zięć Franciszek Siek, naczelnik gminy Wolina. AAP, Tp., TpR 2, Racławice 19 października 1913, Akt fundacyjny, s. 12-13: TpR 1, Racławice, 11 listopada 1913, List ks. Wojciecha Sapeckiego do konsystorza Biskupiego w Przemyślu. 
d. Piwnicy murowanej.

Ogrodzenie drewniane w dobrym stanie.

2. Wikarówka mieści się na plebanii.

[s. 7]

B.

Inwentarz probostwa

I.

Plebania - budynek murowany, odnowiony w r. 1930. Składa się z 10 ubikacji, w skład których wchodzą 2 pokoje z przedsionkiem jako mieszkanie ks. wikarego. W r. 1932 zbudowano nowy, drewniany ganek w miejsce starego.

II.

Archiwum kościelne

1. Libri baptisatorum 12

3 ks[ięgi] gromady Przędzel od r. 1826-1904

1 ks[ięga] gromad Wolina, Nowa Wieś od r. 1826-1904

$1 \mathrm{ks}$ [ięga] gromady Nowosielec od r. 1826-1904

1 ks[ięga] gromady Racławice od r. 1826-1904

1 ks[ięga] gromad Racławice, Podwolina, Nowosielec od r. 1905-1925

1 ks[ięga] gromady Przędzel od r. 1905-1925

$1 \mathrm{ks}$ [ięga] gromady Wolina od r. 1905-1925

1 ks[ięga] gromad Racławice, Podwolina, Nowosielec od r. 1926-

1 ks[ięga] gromady Przędzel od r. 1926-

1 księga gromady Nowa Wieś od r. 1905-

2. Libri copulatorum 6

1 ks[ięga] gromady Przędzel od r. 1826-1904

1 ks[ięga] gromady Racławice od r. 1826-1904

1 ks[ięga] gromad Wolina, Nowa Wieś od r. 1826-1904

$1 \mathrm{ks}$ [ięga] gromady Nowosielec od r. 1826-1904

1 ks[ięga] dla wszystkich gromad ex libro bannorum od 1915-1925

1 dla wszystkich gromad par[afii] od r. 1923-

3. Libri mortuorum 6

1 ks[ięga] gromady Przędzel od r. 1826-1904

1 ks[ięga] gromad Wolina, Nowa Wieś od r. 1826-1904

$1 \mathrm{ks}$ [ięga] gromady Racławice od r. 1826-1904

1 ks[ięga] gromady Nowosielec od r. 1826-1904

1 dla całej parafii od r. 1915-1923

1 dla całej parafii od r. 1924-

4. Liber infirmorum 1

5. Liber protokołu przedślubnego

6. Liber status animarum (niekompletny) 
7. Liber bannorum ab anno 1926

8. 4 extracta mortuorum 1826-1904 par[afia] Nisko

3 extracta copulatorum

8 extracta natorum

9. 3 veteres libri bannorum a varius annis ab a. 1862

10. Extracta baptisatorum totae parochiae ab 1906-192835

11. 2 zwoje aktów

12. Series sacerdotum in par[ochiae] Racławice ab a[nno] 1740 z najważniejszymi zapiskami

13. Wszystkie księgi znajdują się w szafie sosnowej z przegrodami - własność parafii.

[s. 8]

III.

Budynki gospodarcze

3. Stodoła drewniana na słupach murowanych, wystawiona w r. 1927 w b[ardzo] dobrym stanie.

4. Stajnia drewniana z r. 1918, a przebudowana w r. 1932, obejmująca osobne pomieszczenie dla bydła, koni oraz świń, kryta dachówką, w dobrym stanie.

5. Szopy 2 (jedna przy stodole na narzędzia gospodarcze, druga przy stajni na drzewo, obydwie pod dachówką).

6. Spichlerz murowany pod blachą, przerobiony z trupiarni.

7. Studnie 2 (jedna betonowa starsza z korytem do pojenia bydła, druga z r. 1929 betonowa na korbę z daszkiem).

IV.

Inwentarz żywy (wg ostatniego protokołu zabezpieczenia)

8. Konie 2, siwe 13-letnie.

9. Krowy 3 oraz 1 jałówka dwuletnia.

V.

Inwentarz martwy

10. Zboża 18 korcy (4,5 owsa; 4,5 jęczmienia; 4,5 żyta; 4,5 pszenicy).

II.

\section{Protokól}

z przejęcia kościoła i probostwa w Racławicach przez Ks. Mieczysława Porawskiego ${ }^{36}$, wikariusza, substytuta, z rąk Ks. Franciszka Zmarzłego, proboszcza w Racławicach, udają-

\footnotetext{
35 8-10 połączone klamrą z napisem: nieoprawne.

36 Ks. Mieczysław Porawski (1919-2007). Pochodził z Zarszyna. Uczył się w gimnazjum w Przemyślu, po czym 1939 r. wstąpił do Wyższego Seminarium Duchownego. Święcenia kapłańskie przyjął 24 października 1943 r. w Starej Wsi z rąk biskupa Franciszka Bardy (1880-1964). Jako wikariusz pracował w parafiach: Lesko, Dydnia,
} 
cego się na roczny urlop, spisany w obecności ks. Wincentego Boczara ${ }^{37}$, dziekana dekanatu rudnickiego, w Racławicach, dnia 10 października 1954 r.

Przy przeglądaniu części składowych majątku kościelnego i plebańskiego i przy porównaniu stanu aktualnego z „Inwentarzem Parafialnym” stwierdzono następujące różnice:

\section{A. Inwentarz kościoła}

Wśród sprzętów kościelnych ubyło: Dzwon z wieży i sygnaturka, zarekwirowane przez niemieckiego okupanta w r. 1941. Ponadto starte zostało przez używanie złocenie z dwóch kielichów. Drewniane ogrodzenie wokół kościoła, zniszczone wskutek starości, wymaga rychłej zmiany. Kostnica na cmentarzu grzebalnym, zdewastowana w czasie wojny, wymaga gruntownego remontu.

Przybyło: Nowa sygnaturka, chrzcielnica dębowa - ozdobiona ornamentem, rzeźbionym w drzewie lipowym; tron eucharystyczny, metalowy z firankami, wysoki na $1 \mathrm{~m}$; jedna monstrancja metalowa, pozłacana, wysoka na $65 \mathrm{~cm}$, z wianuszkiem o 6 medalionach srebrnych; futerał drewniany na monstrancję; jeden kielich srebrny, pozłacany; jeden żyrandol metalowy o 42 świecach elektrycznych; jeden zegar ścienny, sprężynowy; baldachim z jedwabiu, haftowany maszynowo; szafa sosnowa na ornaty; jedna kapa czerwona, nowa, z szychem złotym; cztery ornaty, w tym: jeden czerwony z kolumną środkową z brokatu, z haftem złotym Chrystusa Króla; jeden zielony, pojedynczy, z haftem złotym IHS; jeden fioletowy, z kolumną haftowaną maszynowo; jeden czarny, z adamaszku, z kolumną środkową haftowaną ręcznie, ze złotym IHS; dwie tuwalnie z białego adamaszku; dwa pokrowce na ołtarze; jedna alba; trzy komże, w tym: jedna płócienna, a dwie z tiulu; dwa obrazy, malowane na płótnie, jeden: kopia Ostatniej Wieczerzy Leonarda da Vinci, drugi: kopia Madonny Rafaela ${ }^{38}$; jeden mszał nowy, oprawny w czerwoną skórkę; jeden mszał żałobny o sztywnej oprawie papierowej. Ponadto w r. 1947 kościół zelektryfikowano oraz pomalowano.

\section{B. Inwentarz probostwa}

Art. I, II, III „Inwentarza Parafialnego” z roku 1940 bez zmian. Wszystkie budynki w dobrym stanie. Dach na plebanii wymaga pewnego remontu. Parkan od strony drogi publicznej nowy. Na rozszerzenie drogi publicznej Prezydium Powiatowej Rady Narodowej

\footnotetext{
Jarosław - kolegiata, Ulanów, zaś od 1954 r. początkowo wikariusz, następnie administrator, a od 1956 r. proboszcz w Racławicach do 2000 r. Kapelan Honorowy Jego Świątobliwości od 1997 r., Kanonik Honorowy Kapituły Konkatedralnej w Stalowej Woli od 1994 r. Ofiarne życie księdza Mieczysława Porawskiego, red. B. Barć, Sandomierz 2017.

37 Ks. Wincenty Boczar (1887-1960) pochodził z Iwonicza. Uczył się w Sanoku i Przemyślu. Wyższe Seminarium Duchowne w Przemyślu ukończył w 1912 r., przyjmując 29 czerwca święcenia kapłańskie z rąk biskupa Józefa Sebastiana Pelczara. Jako wikariusz pracował w: Gorlicach, Przemyślu, Drohobyczu. W latach $1916-1918$ był kapelanem wojskowym (dosłużył się stopnia majora, otrzymał Krzyż Niepodległości). Od 1919 r. był proboszczem w Rzepienniku Biskupim, od 1925 r. w Jaćmierzu, zaś od 1929 r. w Zgłobniu. W 1938 r. otrzymał probostwo w Niżankowicach, jednakże po wkroczeniu wojsk radzieckich, musiał opuścić parafię. Administrował kolejno w parafiach: Handzlówka, Dzikowiec, Jaśliska, Harta, od 1940 r. Nisko, gdzie w dwa lata później został do śmierci proboszczem. Od 15 lutego 1952 r. dziekan rudnicki. Odznaczony „Expositorio Canonicale” w 1927 r. oraz w tymże roku przywilejem noszenia rokiety i mantoletu. S. Zych, B. Walicki, Działalność duszpasterska ks. Wincentego Boczara, „Rocznik Kolbuszowski”, 14 (2014), s. 321-334.

38 Obrazy były autorstwa Marii Waldeck.
} 
w Nisku zabrało bez odszkodowania około $600 \mathrm{~m}^{2}$ ogrodu wraz z osiemnastoma drzewami owocowymi.

Art. IV. Inwentarz żywy. Zastano dwa konie: jeden wiśniowo-gniady jedenastoletni, drugi kasztanowaty ośmioletni. Krowy trzy: ośmioletnia, sześcioletnia i trzyletnia. Jałówki, o której wspomina protokół z zabezpieczenia majątku beneficjalnego z dnia 11 sierpnia 1930 r. i którą wymienia „Inwentarz Parafialny” z roku 1940, nie zastano. Ks. proboszcz Franciszek Zmarzły twierdzi, że jałówki wymienionej przez ów protokół, podpisany przez niego w chwili przyjmowania beneficjum, prawdopodobnie nie otrzymał.

Art. V. Inwentarz martwy. Ks. Franciszek Zmarzły wysiał w jesieni br. 120 kg pszenicy. W odsypach Ks. Proboszcz oddaje Ks. Substytutowi: 330 kg pszenicy, cztery i pół korcy żyta oraz dziewięć korcy owsa. Ponadto Ks. Proboszcz zostawia Ks. M. Porawskiemu 37 cetnarów ziemniaków jadalnych oraz siano i koniczynę na wyżywienie bydła, za co Ks. Porawski zobowiązuje się wypłacać Ks. Zmarzłemu 30\% dochodów z ,iura stolae”.

[s. 2]

Ks. Mieczysław Porawski zobowiązuje się pokrywać wszelkie ciężary podatkowe zarówno pieniężne jak i rzeczowe za rok 1955. Msze św. „pro parochianis” odprawiał będzie Ks. Substytut.

Protokół niniejszy sporządza się w dwóch jednobrzmiących egzemplarzach, z których jeden pozostaje w archiwum parafialnym, drugi zaś odsyła się do Kurii Biskupiej w Przemyślu.

Na tym protokół zakończono i po przeczytaniu podpisano.

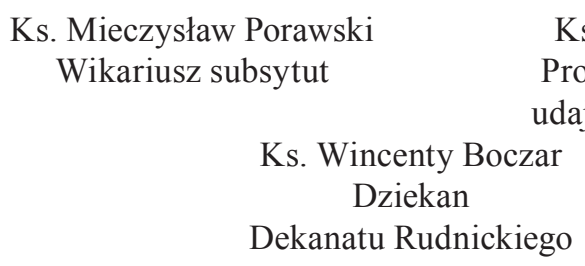

\section{Bibliografia}

\section{Archiwum Archidiecezji Przemyskiej}

- Akta personalne księży.

- Teczka z ankietami z 1945 r. o stanie parafii w czasie II wojny światowej.

- Teczki parafialne - Teczki parafii Racławice.

\section{Archiwum Parafii Raclawice}

- Dokumenty luźne.

- Teczka z dyplomami.

- Księga dochodów i rozchodów.

\section{Opracowania}

Barć B., Mieczysław Fusek, w: Przeszli przez tę ziemię czyniąc dobro. Cmentarz w Racławicach, red. B. Barć, Stalowa Wola 2012, s. 96. 
Borcz H., Kopeć Józef, w: Słownik biograficzny duchowieństwa metropolii lwowskiej obrządku łacińskiego ofiar II wojny światowej 1939-1945, red. J. Krętosz, M. Pawłowiczowa, Opole 2007, s. 103-104.

Encyklopedia wiedzy o jezuitach na ziemiach Polski i Litwy 1564-1995, opr. Ludwik Grzebień, Kraków 1996.

Gurba S., Twórczość artystyczna Marii Waldeck - malarki z Królewskiej Wsi Pysznica, „Kronika Diecezji Sandomierskiej”, 107 (2014), nr 5-6, s. 391-396.

Kowalski W., Uposażenie parafii archidiakonatu sandomierskiego w XV-XVIII wieku, Kielce 1998.

Kracik J., Konsekracje kościołów i ottarzy w diecezji krakowskiej w XVII-XVIII w., „Nasza Przeszłość", 61 (1984), s. 111-147.

Kumor B., Dzieje diecezji krakowskiej do roku 1795, t. 4, Kraków 2002.

Kumor B., Ustrój i organizacja Kościoła polskiego w okresie niewoli narodowej 1772-1918, Kraków 1980.

Moskal T., Duszpasterze parafii Racławice w latach 1918-1939, „Archiwa Biblioteki i Muzea Kościelne", 92 (2009), s. 165-176.

Ofiarne życie księdza Mieczysława Porawskiego, red. B. Barć, Sandomierz 2017.

Rawski J., Wybrane zagadnienia dotyczace administracji kościelnej w widłach Wisty $i$ Sanu, Tarnobrzeg 1997.

Rocznik Diecezji Sandomierskiej 1994, red. Z. Kończak, Sandomierz 1994.

Sprawozdanie z pracy katolicko-społecznej w diecezji przemyskiej za czas od sierpnia 1911 roku, tj. od Kongresu Mariańskiego, do czerwca 1914 r., „Kronika Diecezji Przemyskiej”, 14 (1914), z. 6, s. 367-370.

Wiśniewski J., Katalog prałatów i kanoników sandomierskich od 1186 do 1926 r. tudzież sesje kapituty sandomierskiej od 1581 do 1866 r., Radom 1928.

Wykaz kościołów diecezji przemyskiej ob. łać. wskutek wojny całkowicie zniszczonych lub częściowo uszkodzonych, „Kronika Diecezji Przemyskiej”, 17 (1917), s. 43-51.

Zabytkowe cmentarze i mogity w Polsce. Województwo tarnobrzeskie, opr. M. Florek, Warszawa 1995.

Zych S., Walicki B., Działalność duszpasterska ks. Wincentego Boczara. „,Rocznik Kolbuszowski”, 14 (2014), s. 321-334. 